\title{
Effects of quetiapine on body mass index and reproductive hormonal levels in male schizophrenic patients
}

\author{
Imad A. Thanoon, Shamil H. Othman, Omar M. Y. Shindalla \\ Department of Pharmacology, College of Medicine, University of Mosul.
}

(Ann. Coll. Med. Mosul 2011; 37 (1 \& 2): 110-113).

Received: $29^{\text {th }}$ Mar 2011; Accepted: $10^{\text {th }}$ Oct 2011.

\begin{abstract}
Objective: To asses the effects of quetiapine therapy on body mass index (BMI) and serum level of testosterone, prolactin, follicle stimulating hormone (FSH), luteinizing hormone (LH), and estradiol (E2) in newly diagnosed male schizophrenic patients in comparison to healthy controls.

Patients and methods: Thirty male patients with schizophrenia were included in this study. The diagnosis of schizophrenia was made according to DSM-IV criteria of the American Psychiatric Association (APA). Another thirty apparently healthy male individuals were included in the study as a control group. Blood samples were taken initially from patients and controls and assay of serum testosterone, prolactin, $\mathrm{FSH}, \mathrm{LH}$, and E2 were done using enzyme -linked fluorescent immunoassay (ELFA) technique by vidas instrument. Later, after 6 months of quetiapine therapy, other blood samples were taken and assay of the same parameters were done. Calculation of BMI was done for the patients and controls using special equation.

Results: There was an insignificant difference in the mean BMI, serum testosterone, prolactin, FSH, $\mathrm{LH}$, and E2 levels between patients in the pre-therapy stage group and in both the post-therapy stage group and controls.
\end{abstract}

Conclusion: Chronic quetiapine therapy might be regarded as a safe drug with regard to effects on $\mathrm{BMI}$ and serum levels of reproductive hormones in newly diagnosed male schizophrenic patients.

Keywords: Schizophrenia, quetiapine, BMI, testosterone, prolactin, FSH, LH, E2.

الخلاصة

الأهداف: لتقييم تاثير علاح الكويتابين على دليل كتلة الجسم، ومستوى الهرمونات التناسلية في مصل الدم مثل هرمون الثحمون الخصوي، هرمون الحليب، هرمون المحفز للجريبي، هرمون اللوتين وهرمون استرادايول عند الذكور

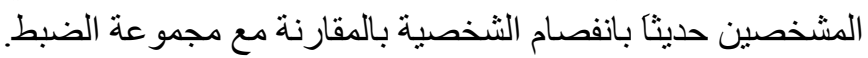

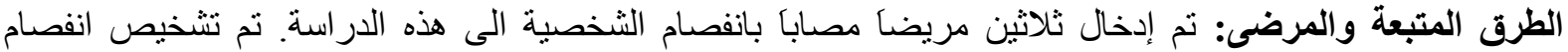

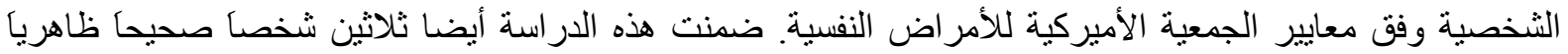

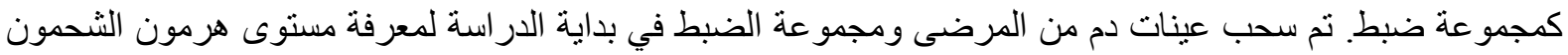
الخصوي، هرمون الحليب، الهرمون المحفز للجريبي، هرمون اللوتين وهرمون استر ادايول في مصل الدم باستخدام تقنية enzyme -linked fluorescent assay شهور، وفي نهاية الفترة المقترحة للمتابعة تم سحب عينات دم أخرى من المرضى لمعرفة مستويات الهرمونات المذكورة

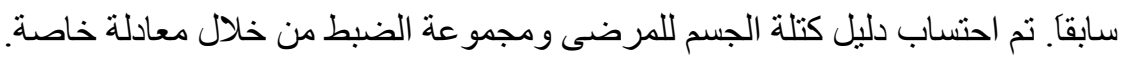

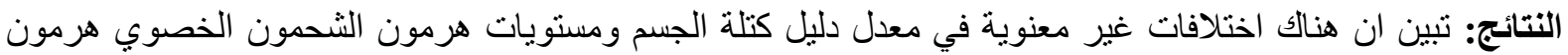
الحليب، الهرمون المحفز للجريبي، هرمون اللوتين وهرمون استرادايول في مصل الدم لدى الدئ المرضى في مرحلة قبل العلاج وبعده بالمقارنة مع مجمو عة الضبط. 
الاستتتاج: ان العلاج المزمن بعقار الكويتابين (علاج غير نموذجي مضاد للانفصام) قد يكون من الأدوية الأمينة فيما

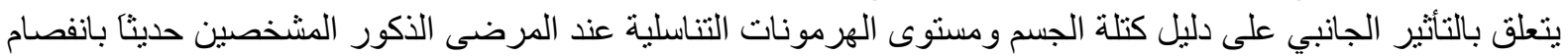
الشخصية .

كلمات الدلالة: انفصام الثخصية، كويتابين، دليل كتلة الجسم، هرمون الثحمون الخصوي، هرمون الحليب، الهرمون

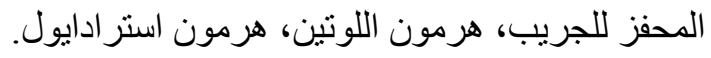

$\mathrm{Q}$ uetiapine (atypical antipsychotic drug) is a novel dibenzo-thiazepine antipsychotic drug developed by Zeneca Pharmaceuticals in 1985. It is marketed under the trade name Seroquel ${ }^{(1)}$. It was approved in September 1997 by the Food and Drug Administration (FDA) and has since been introduced in most western European countries as well as in 70 other countries worldwide for the treatment of schizophrenia and related psychotic illnesses

(2). The use of atypical or second generation antipsychotic drugs is gaining popularity as a result of their tolerability and efficacy ${ }^{(3)}$. However, the use of these drugs has been associated with metabolic and endocrinal adverse effects beside their effects on body weight ${ }^{(4,5)}$.

According to our knowledge, no study was done previously evaluating the effect of quetiapine on $\mathrm{BMI}$, testosterone, prolactin, $\mathrm{FSH}, \mathrm{LH}$ and E2, so the present study was conducted to assess the effect of quetiapine therapy on such parameters in newly diagnosed male schizophrenic patients.

\section{Patients and methods}

Out of the 37 selected newly diagnosed patients with schizophrenia, only 30 patients completed the study. Patients were referred from private psychiatric clinics. The criteria of selection included: newly diagnosed male patients, above the age of 20 years (mean \pm SD 33.70 \pm 6.17 years, ranged between 21 and 41 years), cooperative relatives, no other diseases (cardiovascular, hepatic, renal or endocrinal). Diagnosis of schizophrenia was made according to DSM-IV criteria of American Psychiatric Association (APA). Another thirty healthy male individuals above the age of 20 years (mean \pm SD $32.62 \pm 5.06$ years, ranged between 21 and 42 years) participated in the study as a control group.
Initially, blood samples were taken from patients and controls and assay of serum levels of testosterone, prolactin, $\mathrm{FSH}, \mathrm{LH}$, and E2 were done using enzyme-linked fluorescent assay (ELFA by VIDAS instrument using commercial kits for each hormone from bioMerieux -Lyon-France). Patients then put on quetiapine (Seroquel) in a daily dose ranged between $200 \mathrm{mg}$ and $400 \mathrm{mg}$ for 6 months. By the end of the suggested period of the study, another blood samples were taken and assay of the same parameters was done. BMI was calculated for both patients and controls using the following equation:

$\mathrm{BMI}=$ Weight $(\mathrm{kg}) /$ Height $\left(\mathrm{m}^{2}\right)^{(6)}$

\section{Statistical methods}

Standard statistical methods were used to determine the mean and standard deviation (SD). Unpaired t-test was used to compare the results of measured parameters of patients in the (pre and post-therapy stages) and controls. Paired t-test was used to compare the results of measured parameters in patients in the preand post- therapy stages. P- values equal or less than 0.05 were considered significant ${ }^{(7)}$.

\section{Results}

There were insignificant differences in the mean values of BMI, serum levels of testosterone, prolactin, $\mathrm{FSH}, \mathrm{LH}$, and E2 in patients in the pre- and post- therapy stages and the controls (Table 1).

There were insignificant differences in the mean values of $\mathrm{BMI}$, serum levels of testosterone, prolactin, $\mathrm{FSH}, \mathrm{LH}$, and $\mathrm{E} 2$ in patients in the pre- and post- therapy stage groups (Table 2). 
Table (1): Comparison of BMI and serum sex hormones levels between patients and control.

\begin{tabular}{|c|c|c|c|}
\hline \multirow{3}{*}{ Parameters } & \multicolumn{3}{|c|}{ Mean \pm SD } \\
\hline & \multicolumn{3}{|c|}{$\mathrm{n}=30$} \\
\hline & Controls & Patients Pre-therapy & Patients post-therapy \\
\hline $\mathrm{BMI}$ & $25.01+2.28$ & $23.91+2.27^{\star \star}$ & $24.37 \pm 2.31^{\star \star}$ \\
\hline Testosterone (ng/ml) & $5.61+1.25$ & $5.72 \pm 1.47^{\star \star}$ & $6.05+1.16^{\star \star}$ \\
\hline Prolactin (ng/ml) & $10.97+2.57$ & $11.89 \pm 6.13^{\star \star}$ & $12.31+2.94^{\star \star}$ \\
\hline $\mathrm{FSH}(\mathrm{m} \mathrm{IU} / \mathrm{ml})$ & $3.69 \pm 0.93$ & $4.18 \pm 2.54^{\star \star}$ & $3.85 \pm 1.50^{\star \star}$ \\
\hline $\mathrm{LH}(\mathrm{m}$ IU/ml) & $3.52 \pm 1.93$ & $3.53+1.65^{\star \star}$ & $3.78 \pm 1.70^{\star \star}$ \\
\hline E2 (pg/ml) & $27.30 \pm 6.19$ & $28.57 \pm 6.86^{\star \star}$ & $27.88 \pm 6.50$ ** \\
\hline
\end{tabular}

**Non significant difference from control at $p<0.05$.

Table (2): Comparison of BMI and serum sex hormones levels between patients before and after quetiapine therapy.

\begin{tabular}{|c|c|c|c|}
\hline \multirow{3}{*}{ Parameters } & \multicolumn{3}{|c|}{ Mean \pm SD } \\
\hline & \multicolumn{3}{|c|}{$n=30$} \\
\hline & Patients pre- therapy & Patients post-therapy & $\mathrm{p}$ - value \\
\hline BMI & $23.91 \pm 2.27$ & $24.37 \pm 2.31$ & $0.867^{\star}$ \\
\hline Testosterone (ng/ml) & $5.72 \pm 1.47$ & $6.05 \pm 1.16$ & $0.543^{*}$ \\
\hline Prolactin (ng/ml) & $11.89+6.13$ & $12.31 \pm 2.94$ & $0.741^{*}$ \\
\hline $\mathrm{FSH}(\mathrm{m} \mathrm{IU} / \mathrm{ml})$ & $4.18 \pm 2.54$ & $3.85 \pm 1.50$ & $0.634^{*}$ \\
\hline $\mathrm{LH}(\mathrm{m} \mathrm{IU} / \mathrm{ml})$ & $3.53 \pm 1.65$ & $3.78 \pm 1.70$ & $0.637^{*}$ \\
\hline E2 (pg/ml) & $28.57 \pm 6.86$ & $27.88 \pm 6.50$ & $0.446^{*}$ \\
\hline
\end{tabular}

* Non significant difference at $p<0.05$.

\section{Discussion}

The present study demonstrated that schizophrenic patients have normal BMI and that the administration of quetiapine for 6 months to schizophrenic male patients resulted in a non significant effects on BMI and serum levels of testosterone, prolactin, $\mathrm{FSH}$, $\mathrm{LH}$, and E2.

Emsley et al ${ }^{(8)}$, in a randomized control trial, studied the effects of quetiapine and haloperidol on BMI and glycemic control. They reported that switching treatment from a conventional antipsychotic to quetiapine is not associated with weight gain or worsening of glycemic control even in the long term therapy which is also in agreement of this study. Furthermore, Gorobets ${ }^{(5)}$ studied the weight gain in patients with schizophrenia and schizoaffective disorders induced by the long term treatment with atypical antipsychotic drugs. He concluded that long term therapy with olanzepine, clozapine and risperidone exert a more marked influence on the body mass as compared to quetiapine and amrisulpiride regardless of the patient sex, which is consistent with our findings.

Regarding serum levels of reproductive hormones and in agreement with our findings, Kaneda and Ghmor ${ }^{(9)}$, evaluated the effect of quetiapine administration for a mean duration of 104.7 days on hypothalamic-pituitarygonadal axis (HPG) hormones in patients with chronic schizophrenia and reported that quetiapine might not affect prolactin and HPG axis hormones at least in chronic schizophrenic patients with normal levels of HPG axis hormones.

On the same line but with other atypical antipsychotic drugs, Konarzewska et al (10) studied the effects of risperidone and olanzapine on reproductive hormones, psychopathology, and sexual functioning in male patients with schizophrenia. They 
reported that the mean serum prolactin level was markedly higher in patients taking risperidone, whereas FSH levels were lower than in patients receiving olanzapine, and the mean levels of LH, testosterone, and estradiol were within normal reference ranges.

\section{Conclusion}

Chronic quetiapine therapy might be regarded safe, with regard to effects on BMI and serum levels of reproductive hormones in newly diagnosed male patients with schizophrenia.

\section{Acknowledgment}

We wish to express our thanks to Dr. Mahfoudh S. AL-Noaimy (psychiatrist) for his help and support.

\section{References}

1. Liberman JA, Perkins DO. Quetiapine: A5 year update. Introduction. J Clin Psychiatry 2002; 63 (suppl 13):3-4.

2. Nemeroff CB, Kinkead B, Goldstien J. Quetiapine: Preclinical studies, Pharmacokinetics, drug interactions, and dosing. J Clin Psychiatry 2002; 63 (suppl 13): 5-11.

3. Ronald CWM, Alice PSK, Norman C, Peter CYT, Juliana CNC. Drug-induced endocrine and metabolic disorders. Drug safety 2007; 30(3): 215-245.

4. Smith RC, Lindenmayer JP, Bark N, Warner-Cshen J, Vaidhyanathaswamy S, Khandat A. Clozapine, risperidone, olanzapine and conventional antipsychotic drug effects on glucose, lipids, and leptin in schizophrenic patients. Int $\mathrm{J}$ Neuropsychopharmacol 2005; 8(2): 183194.
5. Gorobets LN. Weight gain in patients with schizophrenia and schizoaffective disorder induced by the long- term treatment with atypical antipsychotics. Zh Nevrol Psikhiatr Im SS Krsakova 2008; 108 (9): 52-56.

6. Leermarkers EA, Dunn AL, Blair SN. Exercise management of obesity. Med Clin North America 2000; 84: 41,9-425.

7. Kirkwood BR. Essentials of medical statistics. $\quad 1^{\text {st }}$ edition,1988. Blackwell Scientific Publication, Oxford, p:43-56.

8. Emsley R, Turner HJ, Schronen J, Botha $\mathrm{K}$, Smit R, Oosthuizen PP. Effects of quetiapine and haloperidol on body mass index and glycemic control: a long-term randomized control trial. Int J Neuropsychopharmacol 2005; 8(2):175182.

9. Kaneda $Y$, Ohmor T. Effects of quetiapine on gonadal axis hormones in male patients with schizophrenia: a preliminary, open study. Progress Neuropsychopharmacol Biol Psychiatry 2003; 27(5): 875878.

10. Konarzewska B, Wokzynski S, Szulc A, Galinska B, Poplawska R, Waszkieicz N. Effect of risperidone and olanzapine on reproductive hormones, psychopathology and sexual functioning in male patients with schizophrenia. Psychoneuroendocrinol 2009; 34(1):129-139. 